\title{
Tuning Insect Odorant Receptors
}

\author{
Dieter Wicher* \\ Department of Evolutionary Neuroethology, Max Planck Institute for Chemical Ecology (MPG), Jena, Germany
}

Among the insect olfactory receptors the odorant receptors (ORs) evolved in parallel to the onset of insect flight. A special property of this receptor type is the capability to adjust sensitivity of odor detection according to previous odor contacts. This article presents a current view on regulatory processes affecting the performance of ORs and proposes a model of mechanisms contributing to OR sensitization.

Keywords: chemoreception, olfaction, ionotropic receptor, odorant receptor, receptor kinase, GPCR, intracellular signaling

\section{INTRODUCTION}

The performance of membrane proteins such as ion channels or receptors is dynamically adjusted according to changing physiological requirements. Olfactory receptors have to detect odors in a wide range of concentrations, from faint filaments at larger distance from the source to high concentrated and permanent presence near the source. In mammals, the olfactory receptors for general odors are G protein coupled receptors (GPCRs; Buck and Axel, 1991). For a comparison of vertebrate and insect olfaction see Kaupp (2010), for a recent review of insect olfactory receptors see Fleischer et al. (2018). Three types of receptor proteins detect volatile chemical information in insects. These are odorant receptors (ORs) which are restricted to insects, specific gustatory receptors (GRs) detecting carbon dioxide and receptors related to ionotropic glutamate receptors, called ionotropic receptors (IRs). The ORs evolved in parallel with the onset of insect flight (Missbach et al., 2014). Similar to GPCRs, insect ORs belong to the class of heptahelical transmembrane proteins. But compared with them, the OR proteins show an inverted orientation within the plasma membrane (Benton et al., 2006; Lundin et al., 2007; Smart et al., 2008). Analyzing the variation of insect OR protein amino acids during evolution revealed a model for transmembrane domain arrangement that is unrelated to GPCRs (Hopf et al., 2015).

An insect OR is a heteromeric construct formed by an odor-specific OrX protein and an ubiquitary odorant co-receptor, Orco (Larsson et al., 2004; Neuhaus et al., 2005). Heterologous coexpression of OrX and Orco proteins may in addition to the formation of ORs also lead to Orco homomers (German et al., 2013). It remains to be shown that the ciliar OSN membrane also comprises both types of constructs. At least for the soma membrane the insertion of Orco but not of Or22a/b proteins was demonstrated (Benton et al., 2006).

Experiments in heterologous expression systems supported the view that insect ORs primarily operate as ligand-gated channels (Sato et al., 2008; Wicher et al., 2008). An odor stimulation of sufficient strength produced-independent of $G$ protein activity-an immediate transient response. The ORs form non-selective cation channels which are also permeable for $\mathrm{Ca}^{2+}$. At least some of these OR channels are constitutively active as their expression leads to an elevated level of free $\mathrm{Ca}^{2+}$, even in the absence of a stimulating odor. In addition to the fast ionotropic response there was a slowly developing OR current which relied on G protein function (Wicher et al., 2008). This finding raised the question whether there is also a role of metabotropic signaling in insect olfaction.

Intriguingly, when only Orco proteins are expressed they also form nonselective, $\mathrm{Ca}^{2+}$ permeable cation channels. These channels cannot be activated by odors but by cyclic nucleotides (Wicher et al., 2008). As in the case of ORs, it is presently unknown how the channels are composed of, either as dimers as the heptahelical channel rhodopsin (Müller et al., 2011; Kato et al., 2012), or as 
tetramer like conventional ion channels (Doyle et al., 1998). Orco dimer constructs have properties comparable to those of channels formed by native Orco proteins (Mukunda et al., 2014a).

Orco was found to be necessary for the insertion of the odor-specific receptor proteins into the plasma membrane (Larsson et al., 2004). An important signaling system during development is the hedgehog $(\mathrm{Hh})$ system (Briscoe and Thérond, 2013). The transport of Drosophila ORs to and within the dendritic cilia is regulated by the Hh pathway (Sanchez et al., 2016). The localization of the ORs depends on the distribution of the Hh signal transducer Smoothened (Smo). Smo knockdown flies showed reduced odor responses indicating less expression while mutants in the Smo repressor Patched (Ptc) display largely enhanced odor responses. As $\mathrm{Hh}$ is produced in the OSNs the tuning of OR distribution is an autoregulatory process (Sanchez et al., 2016). Orco proteins possess a putative calmodulin (CaM) binding domain that is well conserved among insect species (Mukunda et al., 2014b). Robust mutations within this region of Orco proteins disrupted the OR traffic to the ciliar membrane (Bahk and Jones, 2016).

\section{G PROTEINS}

That insect ORs-in spite of their inverted membrane topology - can interact with $G$ proteins has been demonstrated for heterologously expressed ORs. Activation of Drosophila Or43a receptor could be monitored when it was coexpressed with the promiscuous $\mathrm{G}$ protein $\alpha$ subunit $\mathrm{G}_{15}$ in Xenopus ooytes (Wetzel et al., 2001). In addition, pheromone-induced activation of the silkmoth Bombyx mori OR-1 and 3 (Grosse-Wilde et al., 2006) and Heliothis virescens HR13 (Grosse-Wilde et al., 2007) coexpressed with $\mathrm{G}_{15}$ in T-Rex293 cells was reflected by calcium signals upon activation of $\mathrm{IP}_{3}$ receptors upon PLC activation via $\mathrm{G}_{15}$.

In the antenna of Drosophila all subunits of heterotrimeric $\mathrm{G}$ proteins were shown to be expressed (Boto et al., 2010). According to immunohistochemical studies, $G_{s}, G_{i}$ and $G_{q} \alpha$ subunits could be detected in the OSNs. This also includes the sensilla along which $G_{i}$ and $G_{q}$ were found, whereas $G_{s}$ staining was seen at the basal segment (Boto et al., 2010). Expression of $G_{s}$ in fly sensilla was also reported, and $G_{s}$ proteins were found to be important for sensitive odor detection (Deng et al., 2011). In the antenna of $B$. mori the three $\alpha$ subunits $\mathrm{G}_{\mathrm{s}}, \mathrm{G}_{\mathrm{i}}$ and $\mathrm{G}_{\mathrm{q}}$ were detected (Miura et al., 2005) while in the mosquito Anopheles females only $\mathrm{G}_{\mathrm{q}}$ was found in certain sensilla (Rützler et al., 2006).

A role of $\mathrm{G}_{\mathrm{o}}$ in Drosophila olfactory reception was shown by expression of the inhibitor pertussis toxin (PTX). Electroantennogram responses and the rise in spike frequency upon odor stimulation were reduced when PTX was expressed in the OSNs (Chatterjee et al., 2009). An effect of $\mathrm{G}_{\mathrm{o} / \mathrm{i}}$ inhibition by PTX was also observed for heterologously expressed ORs (Or22a plus Orco; Ignatious Raja et al., 2014). Monitoring calcium responses in Or22a expressing OSNs to odor stimulation in intact Drosophila antenna revealed weaker responses when $\mathrm{G}_{\mathrm{o} / \mathrm{i}}$ were inhibited (Ignatious Raja et al., 2014). Also the involvement of
$\mathrm{G}_{\mathrm{s}}$ proteins in OR signal transduction was reported (Deng et al., 2011). In addition, other studies demonstrated the importance of $\mathrm{G}_{\mathrm{q}}$ proteins (Kain et al., 2008, 2009). Mutations in $d g q$, the gene encoding the Drosophila $\mathrm{G}_{\mathrm{q}} \alpha$ subunit caused reduced responses to odor stimulation.

In contrast to these findings, only tiny effects in Drosophila sensillum recordings were observed when manipulating the activity of G proteins (Yao and Carlson, 2010). Rather mild effects of $\mathrm{G}$ protein inhibition on $\mathrm{Ca}^{2+}$ responses were seen in heterologously expressed ORs (Smart et al., 2008).

\section{SECOND MESSENGER SYSTEMS}

Independent of $\mathrm{G}$ protein-coupled signal cascades $\mathrm{Ca}^{2+}$ is an ubiquitous messenger that regulates the activity of proteins and links such signaling cascades. OR activation leads to $\mathrm{Ca}^{2+}$ influx into OSNs. Prolonged odor stimuli lead to a $\mathrm{Ca}^{2+}$-induced adaptation of the odor response (Cao et al., 2016). On the other hand, CaM activity can enhance the OR response to moderate stimuli (Mukunda et al., 2014b).

Mutations in the cascade downstream $\mathrm{G}_{\mathrm{s}}$, i.e., in the adenylyl cyclase rutabaga and in the phosphodiesterase dunce affected the olfaction-guided behavior (Martín et al., 2001). Especially overexpression of dunce in specific OSNs which diminished the cAMP level in these cells produced severe phenotypes (Gomez-Diaz et al., 2004). A reduced cAMP level impairs the ability of flies to correctly detect an odor (Murmu and Martin, 2016). On the other hand, odor stimulation leads to enhanced cAMP production (Miazzi et al., 2016). That this effect was related to ORs had been suggested by the finding that odor stimulation of ORs expressed in HEK293 cells gave rise to enhanced cAMP production (Wicher et al., 2008). Artificially enhancing the cAMP concentration in Drosophila OSNs by injecting the membrane-permeable 8-bromo-cAMP or the adenylyl cyclase activator forskolin into the base of sensilla enhanced the odor-response and shifted the concentrationdependence towards lower odor concentration (Getahun et al., 2013). Similarly, in flies expressing a light-activated adenylyl cyclase in OSNs the spike activity could be enhanced by light exposure (Deng et al., 2011).

The signaling cascade downstream $\mathrm{G}_{\mathrm{q}}$ also plays a role in odorant signal processing of insects (Krieger and Breer, 1999; Kain et al., 2008). In the hawkmoth Manduca sexta, pheromone stimuli are detected via PLC-dependent signaling (review, Stengl, 2010). Short and faint pheromone presentation causes an immediate increase spike activity in the receptor neuron which is accompanied by a transient rise in $\mathrm{IP}_{3}$ (Breer et al., 1990; Boekhoff et al., 1993). In cultured receptor neurons, $\mathrm{IP}_{3}$ perfusion opened a $\mathrm{Ca}^{2+}$ channel, the $\mathrm{Ca}^{2+}$ rise in turn activated further types of ion channels (Stengl et al., 1992; Stengl, 1993, 1994). While the pheromone signal transduction in Manduca seems to employ solely metabotropic mechanisms (Nolte et al., 2013, 2016), heterologously expressed pheromone receptors of the silkmoth Bombyx mori were found to act as ligand-gated channels (Sato et al., 2008). This indicates that pheromone signals might be processed via ionotropic and/or metabotropic mechanisms. 
In Drosophila, norpA mutants that express a PLC enzyme with impaired function show reduced odorant responses (RiesgoEscovar et al., 1995). An attenuation of odor responses was also observed in plc21 mutants which express another defective PLC protein (Kain et al., 2008). Mutants in stmbhA, a gene encoding a putative $\mathrm{PIP}_{2}$-DAG lipase, show a markedly reduced electroantennogram response to odor stimulation (Kain et al., 2009). Thus, a disturbed $\mathrm{PIP}_{2}$ cleavage and regeneration cycle negatively affects odor information processing in insect OSNs.

$\mathrm{Ca}^{2+}$ signaling is employed by various pathways necessary for appropriate odor perception. One aspect of the $\mathrm{G}_{\mathrm{q}}$ signaling cascade are $\mathrm{Ca}^{2+}$ signals produced when the $\mathrm{PIP}_{2}$ cleavage product $\mathrm{IP}_{3}$ activates $\mathrm{IP}_{3}$ receptors $\left(\mathrm{IP}_{3} \mathrm{Rs}\right)$ which release $\mathrm{Ca}^{2+}$ from the endoplasmic reticulum. In mutants with disrupted RyR and $\mathrm{IP}_{3} \mathrm{R}$ signaling the adaptation to odor signals is impaired (Murmu et al., 2011; Murmu and Martin, 2016). A role of intracellular stores for odor signal amplification was also observed in vitro (Ignatious Raja et al., 2014). In mammals, a broad dynamic range of the OSNs in terms of odor concentration relies on a proper function of mitochondria (Fluegge et al., 2012).

There is also a crosstalk between the $\mathrm{G}_{\mathrm{s}}$ signaling cascade and intracellular $\mathrm{Ca}^{2+}$ signaling. Given that Orco proteins form cyclic nucleotide-activated ion channels permeable to $\mathrm{Ca}^{2+}$ (Wicher et al., 2008), an enhanced cAMP production may stimulate a $\mathrm{Ca}^{2+}$ influx into the OSNs.

Depending on the situation alternative messenger systems may be recruited while others are switched off. In Manduca pheromone receptor neurons, strong stimuli activate receptor guanylyl cyclases which lead to prolonged adaptation of neuronal activity. Furthermore, in the activity state the basal cAMP level is elevated, e.g., by octopaminergic signaling (Flecke et al., 2010), whereas the cGMP level is low, while at rest the cGMP level rises and the cAMP level drops (review see Stengl, 2010).

Second messenger signaling usually takes place within the sensory neuron. For silkmoth sex pheromone receptors an extracellular modulation has been observed (Nakagawa and Touhara, 2014). Extracellularly presented cyclic nucleotides were seen to weakly activate the Bombyx Or1/Orco complex and to inhibit the response to the sex pheromone bombykol.

\section{SENSITIZATION OF OR RESPONSE}

Stimulation of ORs with highly diluted odor below the detection threshold does not enhance the activity of the OSN (Figure 1A). However, when after a couple of seconds the same stimulus is presented again, the OSN can now respond with transiently enhanced spike frequency (Getahun et al., 2013). Similarly, an enhanced response after repeated gentle stimulation also leads to a rise in the intracellular $\mathrm{Ca}^{2+}$ concentration (Figure 1B, Mukunda et al., 2016). Thus, there must be an up-regulation of OR sensitivity during the interval between these stimuli. This sensitization could be mimicked by upregulation of cAMP production with the adenylyl cyclase activator forskolin. On the other hand, the OR sensitization can be suppressed by inhibition of cAMP
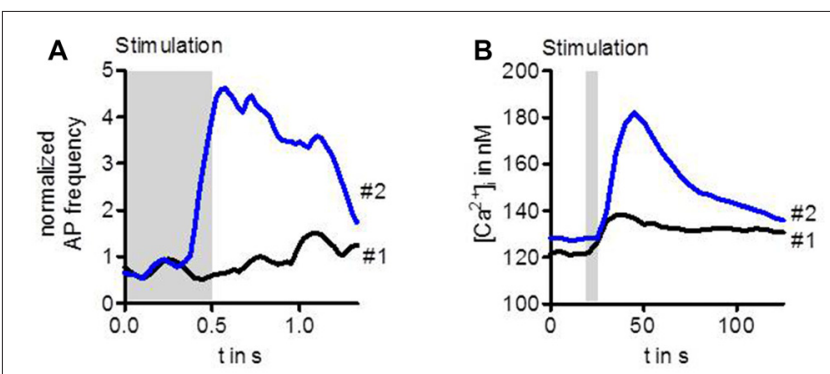

FIGURE 1 | Sensitization observed in the activity of Drosophila OSNs (A) and in $\mathrm{Ca}^{2+}$ level of cultured cells expressing odorant receptors (ORs) (B). The first weak odor stimulation did not enhance the spike frequency in OSNs

expressing Or22a. However, the same stimulus repeated $20 \mathrm{~s}$ later elicited a robust increase in OSN activity (A). Similarly, a first stimulation of HEK293 cells expressing Or22a + Orco enhanced the intracellular $\mathrm{Ca}^{2+}$ concentration $\left[\mathrm{Ca}^{2+}\right]_{\mathrm{i}}$ only slightly whereas the second stimulus led to a strong rise (B). For experimental information see Getahun et al. (2013) (A) and Mukunda et al. (2016) (B)

production (Getahun et al., 2013). Another way to mimick sensitization is to activate protein kinase C (PKC; Getahun et al., 2013).

Thus a main player in the sensitization process seems to be a protein affected by cAMP and PKC. A known target for cAMP and PKC is Orco. Heterologously expressed Orco proteins form ion channels activated by cyclic nucleotides (Wicher et al., 2008). Orco activation by cAMP requires a certain level of phosphorylation by PKC (Sargsyan et al., 2011). The Orco PKC site S289 was seen to be specifically important for OR sensitivity (Guo et al., 2017).

With strong intracellular $\mathrm{Ca}^{2+}$ buffering that inactivates $\mathrm{PKC}$, no Orco activation by cyclic nucleotides could be observed (Sato et al., 2008; Jones et al., 2011). On the other hand, PKC phosphorylation can activate Orco even in the absence of cAMP (Sargsyan et al., 2011). An Orco mutant that cannot be phosphorylated by $\mathrm{PKC}$ is insensitive to cAMP, i.e., the ion channel formed by Orco cannot be activated by cAMP (Sargsyan et al., 2011). In flies expressing this modified Orco protein the OR sensitivity is not enhanced by repeated odor stimulation at subthreshold concentration (Getahun et al., 2013). Also a forskolin-induced stimulation of cAMP production did not enhance the odor response as it was observed in wt flies.

When a rise in the cAMP level may sensitize ORs, the question arises whether an odor stimulus could initiate cAMP production. Using flies in which the OR-expressing OSNs coexpress a cAMP reporter, it was found that indeed odor stimulation caused an increase in cAMP concentration (Miazzi et al., 2016). Interestingly, in OSNs that lack an odor-specific OR protein but express Orco, odor stimuli did not change the cAMP level but Orco activation by the synthetic agonist VUAA1 let to a rise in CAMP. This might be due to activation of a $\mathrm{Ca}^{2+}$ dependent adenylyl cyclase as depolarization had the same effect (Miazzi et al., 2016).

These results are compatible with the following model of OR sensitization (Figure 2). An odor stimulus too weak to robustly activate the OR channel leads to OrX-dependent and/or 


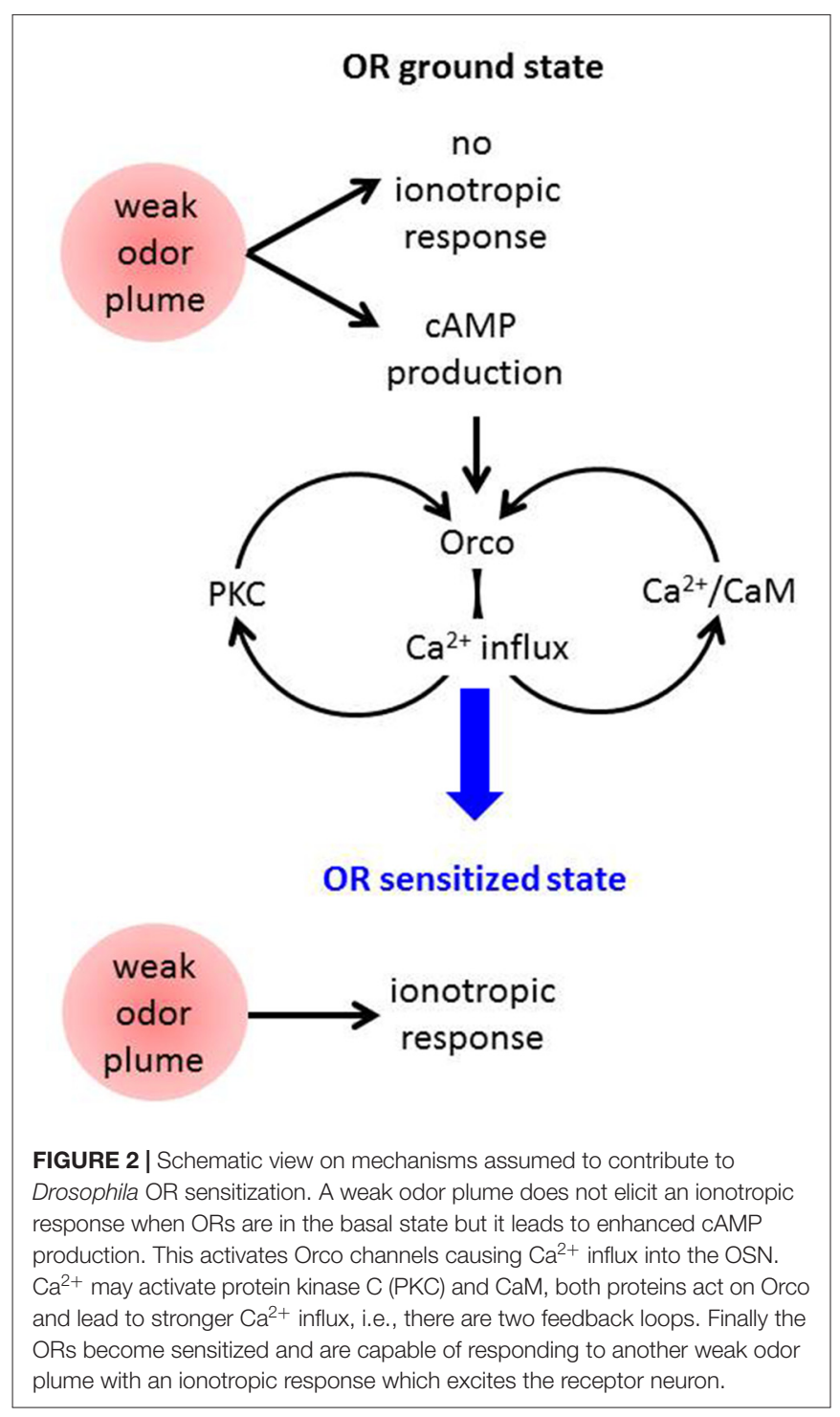

$\mathrm{Ca}^{2+}$-dependent cAMP production (Miazzi et al., 2016). cAMP in turn activates Orco which causes a cation influx including $\mathrm{Ca}^{2+}$ import. This may activate two feedback loops. First, $\mathrm{Ca}^{2+}$-activated calmodulin (CaM) can bind to Orco and enhance the $\mathrm{Ca}^{2+}$ influx (Mukunda et al., 2014b). The requirement of $\mathrm{CaM}$ function for OR sensitization has already been shown (Mukunda et al., 2016). And second, $\mathrm{Ca}^{2+}$ may activate PKC enzymes to phosphorylate Orco which also enhances the ion flow through these channels (Sargsyan et al., 2011). Taken together, the parallel signaling loops via $\mathrm{PKC}$ and $\mathrm{CaM}$ initiated by cAMP-induced $\mathrm{Ca}^{2+}$ influx through Orco both amplify the $\mathrm{Ca}^{2+}$ influx further until the ORs are tuned to the deserved sensitivity. In terms of this model also other sources of intracellular $\mathrm{Ca}^{2+}$ signals, e.g., from intracellular stores might initiate these loops. Even Orco may provide such signal as it was seen to show constitutive activity (Wicher et al., 2008).

In addition to improve the performance of Orco, CaM can also modify the function of the OR constructs which depends on the odor-specific OrX protein (Mukunda et al., 2014b). In this study it was, for example, observed that CaM markedly prolonged the current through the Drosophila geosmin receptor Or56a/Orco that detects the presence of harmful microbes (Stensmyr et al., 2012).

Among the insect olfactory receptors the ability to become sensitized by repetitive stimulation is restricted to ORs and was not observed with IRs (Getahun et al., 2013). The equipment of flying insects with tunable ORs might have qualified these animals to detect faint odor plumes during flight (Getahun et al., 2016). There are certainly many more mechanisms that contribute to receptor sensitization such as an enhanced OR expression level at a circadian time when flies are highly sensitive to odor cues (Tanoue et al., 2008).

\section{DESENSITIZATION AND ADAPTATION OF OR RESPONSE}

To appropriately process strong and/or maintained odor stimuli the insect olfactory system has to be able to downregulate the response in use-dependent manner. Long lasting stimulation and repetitive stimulation of sufficient strength leads to an adaptation of the OR response which is described by the Weber-Fechner relation (Nagel and Wilson, 2011; Cao et al., 2016). Under these conditions, the odor response becomes reduced and delayed. The $\mathrm{Ca}^{2+}$ influx during stimuli orchestrates the adaptive regulation of odor response (Cao et al., 2016).

One mechanism contributing to adaptation, a downregulation of Orco expression, was observed at elevated temperatures which cause enhanced odor concentration in the gas phase (Riveron et al., 2013) or upon excessive ethanol exposure (Morozova et al., 2006). Another way to reduce the OR sensitivity is Orco dephosphorylation at S289, as observed for prolonged odor exposure (Guo et al., 2017).

An adapting response also allowed to perceive turbulent odor filaments (Gorur-Shandilya et al., 2017). The processing of such stimuli is performed in two steps, first in the adaptation to the average odor strength which delays the response, and second in accelerating the onset of spiking. This in conjunction allows the correctly timed perception of odor plumes independent of their intensity (Gorur-Shandilya et al., 2017; Jacob et al., 2017).

\section{ORCO CHANNEL: PACEMAKER OR REGULATOR?}

A role of Orco as pacemaker channel controlling the activity of OSNs was suggested recently (Stengl and Funk, 2013). Depolarizing ion channels opening in the range of the resting membrane potential are capable of shifting the membrane potential towards the threshold for action potential generation. As Orco proteins form cation channels activated by cyclic

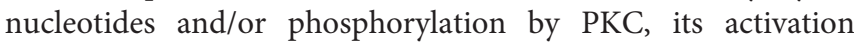
depolarizes the OSN membrane and thus should act as pacemaker (Stengl, 2010; Stengl and Funk, 2013). For Manduca pheromone receptors such a role is compatible with experimental findings (Nolte et al., 2013, 2016). 
In Drosophila OSNs, the background activity is determined by the type of expressed OrX receptor protein (Hallem et al., 2004). The $\Delta$ halo mutant, an ab3A neuron lacking Or22a (Dobritsa et al., 2003), the spontaneous firing rate is very low which indicates a weak or missing pacemaker role of Orco (Hallem et al., 2004). Expression of OrX proteins led to a considerably enhanced spiking. The spike frequency varied between a few $\mathrm{Hz}$ for Or59b or Or22a and $>60 \mathrm{~Hz}$ for Or47b (Hallem et al., 2004). Orco stimulation in Drosophila ab3A neurons with cAMP did not enhance their spontaneous activity (Getahun et al., 2013). However, odor stimulation of Or22a gave rise to a pacemaker activity and accelerates OSN spiking. A strong stimulation of OSN activity was also observed by administration of the synthetic OR agonist VUAA1 (Getahun et al., 2013). Although VUAA1 is capable of activating Orco, it is more efficiently in activation ORs (Jones et al., 2011). These observations support the above notion that in Drosophila OSNs OR activation but not Orco activation produces a pacemaker activity.

The missing pacemaker role of Orco in Drosophila OSNs is surprising insofar as heterologously expressed Orco proteins

\section{REFERENCES}

Bahk, S., and Jones, W. D. (2016). Insect odorant receptor trafficking requires calmodulin. BMC Biol. 14:83. doi: 10.1186/s12915-016-0306-x

Benton, R., Sachse, S., Michnick, S. W., and Vosshall, L. B. (2006). Atypical membrane topology and heteromeric function of Drosophila odorant receptors in vivo. PLoS Biol. 4:e20. doi: 10.1371/journal.pbio.0040020

Boekhoff, I., Seifert, E., Göggerle, S., Lindemann, M., Krüger, B.-W., and Breer, H. (1993). Pheromone-induced second-messenger signaling in insect antennae. Insect Biochem. Mol. Biol. 23, 757-762. doi: 10.1016/0965-1748(93)90063-x

Boto, T., Gomez-Diaz, C., and Alcorta, E. (2010). Expression analysis of the 3 G-protein subunits, $G \alpha, G \beta$, and $G \gamma$, in the olfactory receptor organs of adult Drosophila melanogaster. Chem. Senses 35, 183-193. doi: 10.1093/chemse/bjp095

Breer, H., Boekhoff, I., and Tareilus, E. (1990). Rapid kinetics of second messenger formation in olfactory transduction. Nature 345, 65-68. doi: 10.1038/345065a0

Briscoe, J., and Thérond, P. P. (2013). The mechanisms of Hedgehog signalling and its roles in development and disease. Nat. Rev. Mol. Cell Biol. 14, 416-429. doi: $10.1038 / \mathrm{nrm} 3598$

Buck, L., and Axel, R. (1991). A novel multigene family may encode odorant receptors: a molecular basis for odor recognition. Cell 65, 175-187. doi: 10.1016/0092-8674(91)90418-X

Cao, L. H., Jing, B. Y., Yang, D., Zeng, X., Shen, Y., Tu, Y., et al. (2016). Distinct signaling of Drosophila chemoreceptors in olfactory sensory neurons. Proc. Natl. Acad. Sci. U S A 113, E902-E911. doi: 10.1073/pnas.1518329113

Chatterjee, A., Roman, G., and Hardin, P. E. (2009). Go contributes to olfactory reception in Drosophila melanogaster. BMC Physiol. 9:22. doi: 10.1186/14726793-9-22

Deng, Y., Zhang, W., Farhat, K., Oberland, S., Gisselmann, G., and Neuhaus, E. M. (2011). The stimulatory $\mathrm{G} \alpha_{\text {s }}$ protein is involved in olfactory signal transduction in Drosophila. PLoS One 6:e18605. doi: 10.1371/journal.pone.0018605

Dobritsa, A. A., van der Goes van Naters, W., Warr, C. G., Steinbrecht, R. A., and Carlson, J. R. (2003). Integrating the molecular and cellular basis of odor coding in the Drosophila antenna. Neuron 37, 827-841. doi: 10.1016/s08966273(03)00094-1

Doyle, D. A., Morais Cabral, J., Pfuetzner, R. A., Kuo, A., Gulbis, J. M., Cohen, S. L., et al. (1998). The structure of the potassium channel: molecular basis of $\mathrm{K}^{+}$conduction and selectivity. Science 280, 69-77. doi: 10.1126/science.280. 5360.69

Flecke, C., Nolte, A., and Stengl, M. (2010). Perfusion with cAMP analogue affects pheromone-sensitive trichoid sensilla of the hawkmoth Manduca sexta in a time-dependent manner. J. Exp. Biol. 213, 842-852. doi: 10.1242/jeb.032839 form spontaneously active channels (Sargsyan et al., 2011). And such leaky channels are known to lead to oscillations of the resting membrane potential which facilitates the triggering of action potentials (Stengl, 2010). Probably the number of Orco channels in the ciliar membrane might be too low to provide an efficient pacemaker conductance. By contrast, the $\mathrm{Ca}^{2+}$ influx into the receptor neurons activated by Orco activation would be sufficient to act as intracellular messenger. By this means, $\mathrm{Ca}^{2+}$-dependent proteins such as PLC, PKC or CaM could be activated, thereby facilitating OR sensitization.

\section{AUTHOR CONTRIBUTIONS}

DW wrote the manuscript.

\section{ACKNOWLEDGMENTS}

This study was supported by the Max Planck Society.

Fleischer, J., Pregitzer, P., Breer, H., and Krieger, J. (2018). Access to the odor world: olfactory receptors and their role for signal transduction in insects. Cell. Mol. Life Sci. 75, 485-508. doi: 10.1007/s00018-017 $-2627-5$

Fluegge, D., Moeller, L. M., Cichy, A., Gorin, M., Weth, A., Veitinger, S., et al. (2012). Mitochondrial $\mathrm{Ca}^{2+}$ mobilization is a key element in olfactory signaling. Nat. Neurosci. 15, 754-762. doi: 10.1038/ nn.3074

German, P. F., van der Poel, S., Carraher, C., Kralicek, A. V., and Newcomb, R. D. (2013). Insights into subunit interactions within the insect olfactory receptor complex using FRET. Insect Biochem. Mol. Biol. 43, 138-145. doi: 10.1016/j. ibmb.2012.11.002

Getahun, M. N., Olsson, S. B., Lavista-Llanos, S., Hansson, B. S., and Wicher, D. (2013). Insect odorant response sensitivity is tuned by metabotropically autoregulated olfactory receptors. PLoS One 8:e58889. doi: 10.1371/journal. pone.0058889

Getahun, M. N., Thoma, M., Lavista Llanos, S., Keesey, I., Fandino, R. A., Knaden, M., et al. (2016). Intracellular regulation of the insect chemoreceptor complex impacts odor localization in flying insects. J. Exp. Biol. 219, 3428-3438. doi: 10.1242/jeb.143396

Gomez-Diaz, C., Martin, F., and Alcorta, E. (2004). The cAMP transduction cascade mediates olfactory reception in Drosophila melanogaster. Behav. Genet. 34, 395-406. doi: 10.1023/b:bege.0000023645.02710.fe

Gorur-Shandilya, S., Demir, M., Long, J., Clark, D. A., and Emonet, T. (2017). Olfactory receptor neurons use gain control and complementary kinetics to encode intermittent odorant stimuli. Elife 6:27670. doi: 10.7554/eLife. 27670

Grosse-Wilde, E., Gohl, T., Bouche, E., Breer, H., and Krieger, J. (2007). Candidate pheromone receptors provide the basis for the response of distinct antennal neurons to pheromonal compounds. Eur. J. Neurosci. 25, 2364-2373. doi: 10.1111/j.1460-9568.2007.05512.x

Grosse-Wilde, E., Svatos, A., and Krieger, J. (2006). A pheromone-binding protein mediates the bombykol-induced activation of a pheromone receptor in vitro. Chem. Senses 31, 547-555. doi: 10.1093/chemse/bjj059

Guo, H., Kunwar, K., and Smith, D. (2017). Odorant receptor sensitivity modulation in Drosophila. J. Neurosci. 37, 9465-9473. doi: 10.1523/JNEUROSCI.1573-17.2017

Hallem, E. A., Ho, M. G., and Carlson, J. R. (2004). The molecular basis of odor coding in the Drosophila antenna. Cell 117, 965-979. doi: 10.1016/j.cell.2004. 05.012

Hopf, T. A., Morinaga, S., Ihara, S., Touhara, K., Marks, D. S., and Benton, R. (2015). Amino acid coevolution reveals three-dimensional structure and 
functional domains of insect odorant receptors. Nat. Commun. 6:6077. doi: $10.1038 /$ ncomms7077

Ignatious Raja, J. S., Katanayeva, N., Katanaev, V. L., and Galizia, C. G. (2014). Role of Go/i subgroup of $G$ proteins in olfactory signaling of Drosophila melanogaster. Eur. J. Neurosci. 39, 1245-1255. doi: 10.1111/ejn. 12481

Jacob, V., Monsempes, C., Rospars, J. P., Masson, J. B., and Lucas, P. (2017). Olfactory coding in the turbulent realm. PLoS Comput. Biol. 13:e1005870. doi: 10.1371/journal.pcbi.1005870

Jones, P. L., Pask, G. M., Rinker, D. C., and Zwiebel, L. J. (2011). Functional agonism of insect odorant receptor ion channels. Proc. Natl. Acad. Sci. U S A 108, 8821-8825. doi: 10.1073/pnas. 1102425108

Kain, P., Chakraborty, T. S., Sundaram, S., Siddiqi, O., Rodrigues, V., and Hasan, G. (2008). Reduced odor responses from antennal neurons of $G_{q} \alpha$, phospholipase $\mathrm{C} \beta$, and $\operatorname{rdgA}$ mutants in Drosophila support a role for a phospholipid intermediate in insect olfactory transduction. J. Neurosci. 28, 4745-4755. doi: 10.1523/JNEUROSCI.5306-07.2008

Kain, P., Chandrashekaran, S., Rodrigues, V., and Hasan, G. (2009). Drosophila mutants in phospholipid signaling have reduced olfactory responses as adults and larvae. J. Neurogenet. 23, 303-312. doi: 10.1080/016770608023 72494

Kato, H. E., Zhang, F., Yizhar, O., Ramakrishnan, C., Nishizawa, T., Hirata, K., et al. (2012). Crystal structure of the channelrhodopsin light-gated cation channel. Nature 482, 369-374. doi: 10.1038/nature10870

Kaupp, U. B. (2010). Olfactory signalling in vertebrates and insects: differences and commonalities. Nat. Rev. Neurosci. 11, 188-200. doi: 10.1038/ nrn2789

Krieger, J., and Breer, H. (1999). Olfactory reception in invertebrates. Science 286, 720-723. doi: 10.1126/science.286.5440.720

Larsson, M. C., Domingos, A. I., Jones, W. D., Chiappe, M. E., Amrein, H., and Vosshall, L. B. (2004). Or83b encodes a broadly expressed odorant receptor essential for Drosophila olfaction. Neuron 43, 703-714. doi: 10.1016/j.neuron. 2004.08.019

Lundin, C., Käll, L., Kreher, S. A., Kapp, K., Sonnhammer, E. L., Carlson, J. R., et al. (2007). Membrane topology of the Drosophila OR83b odorant receptor. FEBS Lett. 581, 5601-5604. doi: 10.1016/j.febslet.2007.11.007

Martín, F., Charro, M. J., and Alcorta, E. (2001). Mutations affecting the cAMP transduction pathway modify olfaction in Drosophila. J. Comp. Physiol. A 187, 359-370. doi: 10.1007/s003590100208

Miazzi, F., Hansson, B. S., and Wicher, D. (2016). Odor induced cAMP production in Drosophila melanogaster olfactory sensory neurons. J. Exp. Biol. 219, 1798-1803. doi: 10.1242/jeb.137901

Missbach, C., Dweck, H. K., Vogel, H., Vilcinskas, A., Stensmyr, M. C., Hansson, B. S., et al. (2014). Evolution of insect olfactory receptors. Elife 3:e02115. doi: 10.7554/eLife.02115

Miura, N., Atsumi, S., Tabunoki, H., and Sato, R. (2005). Expression and localization of three $\mathrm{G}$ protein $\alpha$ subunits, Go, Gq, and Gs, in adult antennae of the silkmoth (Bombyx mori). J. Comp. Neurol. 485, 143-152. doi: 10.1002/cne. 20488

Morozova, T. V., Anholt, R. R., and Mackay, T. F. (2006). Transcriptional response to alcohol exposure in Drosophila melanogaster. Genome Biol. 7:R95. doi: 10.1186/gb-2006-7-10-r95

Mukunda, L., Lavista Llanos, S., Hansson, B. S., and Wicher, D. (2014a). Dimerisation of the Drosophila odorant coreceptor Orco. Front. Cell. Neurosci. 8:261. doi: $10.3389 /$ fncel.2014.00261

Mukunda, L., Miazzi, F., Kaltofen, S., Hansson, B. S., and Wicher, D. (2014b). Calmodulin modulates insect odorant receptor function. Cell Calcium 55, 191-199. doi: 10.1016/j.ceca.2014.02.013

Mukunda, L., Miazzi, F., Sargsyan, V., Hansson, B. S., and Wicher, D. (2016). Calmodulin affects sensitization of Drosophila melanogaster odorant receptors. Front. Cell. Neurosci. 10:28. doi: 10.3389/fncel.2016.00028

Müller, M., Bamann, C., Bamberg, E., and Kühlbrandt, W. (2011). Projection structure of channelrhodopsin-2 at 6 A resolution by electron crystallography. J. Mol. Biol. 414, 86-95. doi: 10.1016/j.jmb.2011.09.049

Murmu, M. S., and Martin, J. R. (2016). Interaction between cAMP and intracellular $\mathrm{Ca}^{2+}$-signaling pathways during odor-perception and adaptation in Drosophila. Biochim. Biophys. Acta 1863, 2156-2174. doi: 10.1016/j.bbamcr. 2016.05.014
Murmu, M. S., Stinnakre, J., Real, E., and Martin, J. R. (2011). Calciumstores mediate adaptation in axon terminals of olfactory receptor neurons in Drosophila. BMC Neurosci. 12:105. doi: 10.1186/1471-2202-12-105

Nagel, K. I., and Wilson, R. I. (2011). Biophysical mechanisms underlying olfactory receptor neuron dynamics. Nat. Neurosci. 14, 208-216. doi: 10.1038/ nn. 2725

Nakagawa, T., and Touhara, K. (2014). Extracellular modulation of the silkmoth sex pheromone receptor activity by cyclic nucleotides. PLoS One 8:e63774. doi: 10.1371/journal.pone.0063774

Neuhaus, E. M., Gisselmann, G., Zhang, W., Dooley, R., Störtkuhl, K., and Hatt, H. (2005). Odorant receptor heterodimerization in the olfactory system of Drosophila melanogaster. Nat. Neurosci. 8, 15-17. doi: 10.1038/ nn1371

Nolte, A., Funk, N. W., Mukunda, L., Gawalek, P., Werckenthin, A., Hansson, B. S., et al. (2013). in situ tip-recordings found no evidence for an Orco-based ionotropic mechanism of pheromone-transduction in Manduca sexta. PLoS One 8:e62648. doi: 10.1371/journal.pone.0062648

Nolte, A., Gawalek, P., Koerte, S., Wei, H., Schumann, R., Werckenthin, A., et al. (2016). No evidence for ionotropic pheromone transduction in the hawkmoth Manduca sexta. PLoS One 11:e0166060. doi: 10.1371/journal.pone. 0166060

Riesgo-Escovar, J., Raha, D., and Carlson, J. R. (1995). Requirement for a phospholipase $\mathrm{C}$ in odor response: overlap between olfaction and vision in Drosophila. Proc. Natl. Acad. Sci. U S A 92, 2864-2868. doi: 10.1073/pnas.92. 7.2864

Riveron, J., Boto, T., and Alcorta, E. (2013). Transcriptional basis of the acclimation to high environmental temperature at the olfactory receptor organs of Drosophila melanogaster. BMC Genomics 14:259. doi: 10.1186/1471-216414-259

Rützler, M., Lu, T., and Zwiebel, L. J. (2006). G $\alpha$ encoding gene family of the malaria vector mosquito Anopheles gambiae: expression analysis and immunolocalization of AG $\alpha \mathrm{q}$ and $\mathrm{AG} \alpha \mathrm{o}$ in female antennae. J. Comp. Neurol. 499, 533-545. doi: 10.1002/cne.21083

Sanchez, G. M., Alkhori, L., Hatano, E., Schultz, S. W., Kuzhandaivel, A., Jafari, S., et al. (2016). Hedgehog signaling regulates the ciliary transport of odorant receptors in Drosophila. Cell Rep. 14, 464-470. doi: 10.1016/j.celrep.2015. 12.059

Sargsyan, V., Getahun, M. N., Llanos, S. L., Olsson, S. B., Hansson, B. S., and Wicher, D. (2011). Phosphorylation via PKC regulates the function of the Drosophila odorant coreceptor. Front. Cell. Neurosci. 5:5. doi: 10.3389/fncel. 2011.00005

Sato, K., Pellegrino, M., Nakagawa, T., Nakagawa, T., Vosshall, L. B., and Touhara, K. (2008). Insect olfactory receptors are heteromeric ligand-gated ion channels. Nature 452, 1002-1006. doi: 10.1038/nature06850

Smart, R., Kiely, A., Beale, M., Vargas, E., Carraher, C., Kralicek, A. V., et al. (2008). Drosophila odorant receptors are novel seven transmembrane domain proteins that can signal independently of heterotrimeric G proteins. Insect Biochem. Mol. Biol. 38, 770-780. doi: 10.1016/j.ibmb.2008.05.002

Stengl, M. (1993). Intracellular-messenger-mediated cation channels in cultured olfactory receptor neurons. J. Exp. Biol. 178, 125-147.

Stengl, M. (1994). Inositol-trisphosphate-dependent calcium currents precede cation currents in insect olfactory receptor neurons in vitro. J. Comp. Physiol. A 174, 187-194. doi: 10.1007/bf00193785

Stengl, M. (2010). Pheromone transduction in moths. Front. Cell. Neurosci. 4:133. doi: $10.3389 /$ fncel.2010.00133

Stengl, M., and Funk, N. W. (2013). The role of the coreceptor Orco in insect olfactory transduction. J. Comp. Physiol. A Neuroethol. Sens. Neural. Behav. Physiol. 199, 897-909. doi: 10.1007/s00359-013-0837-3

Stengl, M., Zufall, F., Hatt, H., and Hildebrand, J. G. (1992). Olfactory receptor neurons from antennae of developing male Manduca sexta respond to components of the species-specific sex pheromone in vitro. J. Neurosci. 12, 2523-2531.

Stensmyr, M. C., Dweck, H. K., Farhan, A., Ibba, I., Strutz, A., Mukunda, L. et al. (2012). A conserved dedicated olfactory circuit for detecting harmful microbes in Drosophila. Cell 151, 1345-1357. doi: 10.1016/j.cell.2012. 09.046

Tanoue, S., Krishnan, P., Chatterjee, A., and Hardin, P. E. (2008). G protein-coupled receptor kinase 2 is required for rhythmic olfactory 
responses in Drosophila. Curr. Biol. 18, 787-794. doi: 10.1016/j.cub.2008. 04.062

Wetzel, C. H., Behrendt, H. J., Gisselmann, G., Störtkuhl, K. F., Hovemann, B., and Hatt, H. (2001). Functional expression and characterization of a Drosophila odorant receptor in a heterologous cell system. Proc. Natl. Acad. Sci. U S A 98, 9377-9380. doi: 10.1073/pnas.151103998

Wicher, D., Schäfer, R., Bauernfeind, R., Stensmyr, M. C., Heller, R., Heinemann, S. H., et al. (2008). Drosophila odorant receptors are both ligandgated and cyclic-nucleotide-activated cation channels. Nature 452, 1007-1011. doi: 10.1038/nature06861

Yao, C. A., and Carlson, J. R. (2010). Role of G-proteins in odor-sensing and $\mathrm{CO}_{2}$-sensing neurons in Drosophila. J. Neurosci. 30, 4562-4572. doi: 10.1523/JNEUROSCI.6357-09.2010
Conflict of Interest Statement: The author declares that the research was conducted in the absence of any commercial or financial relationships that could be construed as a potential conflict of interest.

The handling editor is currently co-organizing a Research Topic with the author DW, and confirms the absence of any other collaboration.

Copyright (c) 2018 Wicher. This is an open-access article distributed under the terms of the Creative Commons Attribution License (CC BY). The use, distribution or reproduction in other forums is permitted, provided the original author(s) and the copyright owner are credited and that the original publication in this journal is cited, in accordance with accepted academic practice. No use, distribution or reproduction is permitted which does not comply with these terms. 